\title{
Moving the Posts: Two Models of Sports Research
}

\author{
Torgeir E. Fjeld \\ University of Gdansk, Poland
}

\begin{abstract}
This essay presents two models of sports research, one characterized by a didactic and normative relation to its object, while wedded to a view of language characterized by a transparent and non-mediated relation between signifier and signified, and another result of the linguistic turn and an interest in reception studies and audiences. The latter has failed to deliver on its promise to democratize sports studies, as it has become centrally engaged in mapping audiences as consumers. Through a narrative analysis of three stories by Kafka, the essay shows how these models can be seen as employing specific narrative forms, and how Kafka's last installment in The Hunger Artist sequel offered a different perspective of the relation between art and society. This latter form of narrative may take sports studies beyond the hold of what psychoanalyst Jacques Lacan referred to as the specular phase of subject formation and into an imaginary servitude characteristic of the social "I", formed in the closing phase of the Mirror Stage.
\end{abstract}

Keywords: sport, narrativity, Lacan, the mirror stage, semiotics ${ }^{1}$

\section{The forms in which we imagine society are also forms of storytelling}

The psychoanalyst Jacques Lacan compared the second phase of the mirror stage - the story of how the human subject is brought into being - with a stadium. After a phase where the world appears inchoate, fragmented and disparate, a sense of self - a story about the "I" - is formed through a series of phantasies that signify the subjects's entrance into the symbolic order. This stage, referred to by Lacan as the fiction of the "I", is symbolized as a fortress or, interestingly to their context, a stadium.

As a story of society, then, the stadium signifies a place where the "I" observes itself, where the self is formed in specific contest with other selves. It is a space of rivalry and struggle, and it is perhaps because of these challenging conditions that the ego tends to defend itself in this phase through what Lacan (2006) calls "obsessional inversion" and "isolating processes". The ego wants to be left alone in its specificity: It seeks an articulation that sets it apart from other selves.

This is why it is of some importance to investigate what kinds of stories are being told through the dominant models of sports research. The stadium - this hallowed space of sports - is far from an innocent location of peaceful symbolization of social rivalry, in this view the very place where rivalry and competition are imagined. As a putting-into-play of the kind of inversion typical to this phase of ego formation, sports are commonly enlisted to bolster a set of didactic values associated with public health and a sense of communal belonging, and sports research is more often than not complicit in naturalising ethical values that underpin a culture of competition, heterosexist bodily practices, and so forth.

Torgeir E. Fjeld,Ph.D, Visiting Lecturer, University of Gdansk.

Correspondence concerning this article should be addressed to ul Wita Stwosza 55, 80-555 Gdansk, Poland. E-mail: torgeir_fjeld@yahoo.no. 
This essay seeks to bring attention to a different program of researches, one that perceives sports events as coming-into-being only with the reception of these events by viewers or spectators. This variant of sports research has a descriptive aim, but is nevertheless not entirely detached from the circuit of sports production: Results from such studies may effect changes in sports. While this second model can be seen as a response to the limitations of the first, it nevertheless remains bounded within an economistic view of social relations - a view that Giorgio Agamben has referred to as restricting power to an economy of domination and control (Björk, 2011, p. 128).

They can associate this second model with what has often been referred to as "the linguistic turn". It takes up into itself the possibility of a number of readings or interpretations of sports, rather than the singular and authoritative meaning imposed by the doxa of sports studies. It is not any longer given that sports should mean or entail that spectators feel the urge to engage in physical activity themselves when they watch sports, or that is going to a football game bolsters spectators's sense of social belonging, or, alternatively, engage in a social malediction, such as hooliganism. Sports research is no longer wedded to a perception of language as transparent, as if signifies could be brought directly into the world of research without mediation.

Rather, sports can just as meaningfully be made into academic objects through focus groups, where ethnologists discuss and seek to bring out a variety of structured interpretations of sports events. While, at the outset, this approach to sports promised some kind of democratization of the way they understand that these events, in practice sports have become objects of a world increasingly similar to the universe portrayed by the movie The Truman Show (1998), where every aspect of the protagonist's world is produced by scientific procedures of interpretation and valuation: the main character, Truman, is - without knowing it - the key figure of a reality show, which is continually adjusted according to viewers' shifting preferences and perceptions.

Sports, in this model, is increasingly taking on a character of an all-encompassing consumerist world, even capable of manufacturing new sports, tailored to the sensibilities of a new, global class of sports consumers. It is a kind of real life staged as a semblance deprived of its material weight. Sports, finally, become signifiers available to appropriation and consumption, and what seemed to offer a democratization of sports studies has turned out to be a nightmare of conspicuous commercialization.

What they are confronted with is a movement of posts, in the sense of goal posts, messages or proscribed tasks. The purpose of research is no longer primarily normative, but instead becomes descriptive. While the doxa of sports research continually needs to justify its existence though claiming to pursue socially beneficial values and exposing problematic ones, the linguistic turn and reception studies entailed a changed relation between researcher and sport. Now sports acquire a purpose-free valuation in Kant's aesthetic sense. The researcher should perceive sports as morally detached subjects, and, crucially, postpone judgement, in the way that Kant's ideal observer of art was prescribed to remain non-involved in order to grasp the entirety of art as aesthetic experience. The consequence of this change is that the researcher no longer is primarily interested in sports per se, but, rather, the spectator, viewer or consumer of sports.

This is where they need to review the narratological character of the shift in perspective. Let us investigate how some stories by Kafka can illustrate this shift, beginning with the well-known "Before the Law".

A man from the country seeks entrance into the Law, the gates of which - although apparently open are guarded by a character whose frightening appearance increases with the ageing of the candidate. As the parable ends the guard appears almost omnipotent in relation to the now diminutive man from the country. 
After various attempts at gaining access to the law, including bribery, flattery, trickery, and so on, the languishing candidate ends his pursuit by asking the guard how comes no-one else, through all this time of waiting, ever tried to gain access to the law though this gate. The guard leans over, screaming into the old man's ear in order to be heard, that the reason for this was that the gate was intended only for him.

There are three main interpretations of this event in the literature. First, Massimo Cacciari suggests that the power of the law is established through the impossibility of entering into which is already open. "The open space is a place where one exists, where things are... It is only into places we can open that we can enter. The already-open immobilizes" (Agamben, 2010, p. 30). So this is one reading of "Before the Law": The old man - the candidate - is immobilized, and fails in his pursuits, since the law is already open. He has set himself an impossible task, and is doomed to failure in his oxymoronic aporia.

Second, as Jacques Derrida proposed, the key to the story is to perceive the "event that succeeds in not happening" (Agamben, 2010, p. 30). Again, the parable portrays a failure: It depicts the old man's defeat when faced with the impossible task of the law. While the event succeeds, the man from the country fails in his attempts to gain access.

Against these readings, Agamben proposes his own, in which the old man doesn't fail, but in fact succeeds with his endeavours. The premise of this reading is drawn from a letter Gerschom Scholem wrote to Walter Benjamin where he suggested that the relation to the law should be interpreted as the "nothing of revelation": "a stage where the law continues to confirm itself, since it has force, but where it no longer has meaning" (Agamben, 2010, p. 31). A law that exists in such conditions is to Scholem not only absent, as the law in Kafka's parable, but it appears only as its own non-realizability.

Agamben (2010) claims that this is the key to understand the crisis of legitimation - the nihilism people across the world endure in their relation to the law, and by the term "law", Agamben (2010) refers to the entirety of traditional texts as regulating device. The law has become a nothing of revelation: a force without meaning, a tradition that is maintained purely as its own zero-point.

And it is in this sense that the man from the country succeeds in Agamben's view. "Isn't is so", he asks, "that if the law receives its force from its openness, then the man succeeds in his task: to close the law and thereby eliminate its force" (Agamben, 2010, p. 31).

The narrative form of this parable can be illustrated with a triangular relation, where the man from the country - the candidate - experiences a blockage in his purported quest, and the third person narration suggests that the impossible position of the law - a kind of aidos, an ideal location — gives a place from which the entirety of the parable can be narrated. By closing the law, the possibility of narration is also cordoned off.

Let them compare this to a later Kafka parable with a different narrative situation, "The Hunger Artist". The artist in this story is frustrated in his quest for recognition by the waning interest in his artisanry: Hunger artists draw smaller crowds, they are continually mocked and exposed to distrust and plain defamation from the public, and - towards the end of the story - the hunger artist is found by some guards forgotten and desolate among some hay in his cage.

It is here that he laments the fallen fortunes of the workmanship of his craft in the eyes of the public and declares that only his dedication to some kind of authentic code of hunger artistry obliges him to fulfill the requirements of his trade. The artist's perception of a lack of recognition - his express desire "to be 
remembered" - serves as an occasion to narrate the parable, and yet it does not have the capacity to hinder the fulfilment of narrator's destiny, his completion of the requirements of his craft, the demise of the artist himself.

This is why "The Hunger Artist" does not pose a set of relations strictly analogous to the candidate who sought admittance to the Law, but compares more closely to the Lacanian analyst:the subject-supposed-to-know. His prophetic capacity to foresee the destiny, not only of his own labour, but that of his entire workmanship, is exhaused only when he actually retreats from the cage and from the story: The epilogue is dominated by a panther, whose frustrated will is enormously admired by the new subject of Kafka's universe: the commoner.

On abjecting the subject-supposed-to-know, the common subject now is in a position to enjoy without restraint the display - spectacularly — of the cruelly subdued will of the animal other. Is this not the subject's own lack performed as an index - signified as explicate articulation of the relation between his ideal-ich and the perceived realities of his moods? This carnivalesque condition - the moment when the governers are overthrown and the governed is free to indulge in pleasures that has been denied them - finds its exact inverse in the actual display of suffering that has taken place during the trials of the hunger artist. No longer is the subject denied the projection of pity with the performer. Instead the panther evokes feelings of strength in the audience, as it is allowed to compare its relative ability to act in accordance with its will to the frustrations of the caged beast. It allows the spectator to imagine himself as relatively uncaged - free.

The narrative triangle here is expanded, as can be seen from this illustration. As the Hunger Artist moves from that of an obstacle or obstinate screen for projection of the crowd's phantasies, he comes to occupy the location of a possible narrator of the epilogue, which, coincidentally is also the locus of possible analysis. The analyst, the now-perished hunger artist, does not exist on the same narrative level as the crowd and the panther, but one step removed, and it is this distance that enables a relation of narrator to narratee.

Do these two narrative models not give a fairly precise impression of the two models of sports research? On the one hand, a form that has exhausted its possibilities, a normative type of research that remains locked within a view of language that is chained to an illusion of linguistic transparency, and that must therefore ultimately be closed as a force without meaning, and, on the other, a detached narrator cooly observing an audience's response to a spectacular show, employing the latest offerings in psychoanalytic tools to refine the possibilities of consumption.

And not where they should ask if there is not yet another sense in which we should be moving the posts, a meaning that can establish some kind of location outside and beyond the permissiveness of an order characterised by the self-depreciation associated with what Žižek refers to as an attitude of playful disengagement toward the Master-signifier (Žižek, 2010, p. 134; cf, 2009, p. 70).

The post no longer signifies an attempt to expand the domain of subjectivity associated with an emancipated subject, such as they find in the post-movement Laclau and Mouffe. Sports research is not any longer first and foremost invested in expanding the domain of sports to include hitherto excluded subjects: Women ski jumping, underpriviliged into football, and so on. Rather the challenge of the "post" now entails the conditions of possibility of grasping the spectral logic of a repetition of the law.

To illustrate this last point, let the author finish by briefly knowing Kafka, in the final story of the sequel "The Hunger Artist" the story of "osephine, the Singer, or the Mouse People" offers an entirely different model of society's relation to art. Here the citizens are posed as narrators, while the position that was held by the 
analyst in the Hunger Artist still exists, but is left vacant. The citizens of the story ponder the indeterminacy of their hallowed singer, and vividly portray her beauty, artistic excellence and ambigous character, while the actual Josephine remains absent.

And now, finally, to return to Lacan's third phase of the Mirror Stage, we should ask if this narrative formulae could offer a way out of the deadlock imposed by the two dominant models of sports research. The story of Josephine illustrates the moment in which "the whole of human knowledge tips into mediatization through the desire of the other"(Lacan, 2006, p. 79). The model is no longer present, and only remains as a trace or speculative memory. It is at this moment the subject may revert to a defensive attitude characterized by a sense of "paranoiac alienation", or else engage in the type of "imaginary servitude" associated with what Lacan refered to as the social "I".

And perhaps it is here we should leave the stadium behind and turn to the imaginary possibilities opened up through the kind of enjoyments that may be generated by novel kinds of sports research.

\section{Conclusion}

This paper reviewed literature on youth sport programs, coaches, and parents within the framework of positive and negative outcomes. Implications for sport practitioners and future directions for youth sport researchers were outlined. If researchers and practitioners work together in a collaborative manner, it is most likely more youth will experience positive outcomes through sport, in particular, they will experience better physical health, psychosocial development, and lifelong recreational or elite sport participation.

\section{References}

Agamben, G. (2010). Kafka og lovens rene form. Le Monde diplomatique. 30-31.

Björk, M. (2011). Efter den yttersta domen. Giorgio Agamben om den ekonomiska teologin. Agora 29(4), 127-144.

Derrida, J. (1996). Marx' spфkelser [Spectres de Marx]. Transl. Gundersen, K. Oslo: Pax.

Guéguen,P-G. (2010). On Women and the Phallus. The Symptom, no. 11. Retrieved from http://www.lacan.com/symptom $11 /$ ?p=508

Kafka, F. (1965). I straffekolonien og andre fortellinger. Transl. Brøgger, W. Oslo: Cappelen.

Lacan, J. (2006). The Mirror Stage. Écrits. New York: W.W. Norton \& Co. 75-81.

Laclau, E., \& Mouffe, C. (1985). Hegemony and Socialist Strategy: Towards a Radical Democratic Politics. London: Verso. Peter Weir. ( Director). (1998). The Truman Show.

Žižek, S. (2002). A Plea for Leninist Intolerance. Critical Inquiry, Winter 2002. Retrieved from http://www.egs.edu/faculty/zizek/zizek-a-plea-for-leninist-intolerance.html 